Cite this: RSC Advances, 2013, 3, 2538

Received 19th November 2012, Accepted 20th December 2012

DOI: $10.1039 / \mathrm{c} 2 \mathrm{ra} 23365 \mathrm{~g}$

www.rsc.org/advances

\section{High-performance Si anodes with a highly conductive and thermally stable titanium silicide coating layert}

\author{
Okji Park, Jung-In Lee, Myung-Jin Chun, Jin-Tak Yeon, Seungmin Yoo, Sinho Choi, \\ Nam-Soon Choi* and Soojin Park*
}

We report a simple route for synthesizing titanium silicide-coated $\mathrm{Si}$ anodes via the silicothermic reduction process of $\mathrm{TiO}_{2}$-coated $\mathrm{Si}$. The titanium silicide enhances the electrical conductivity of $\mathrm{Si}$ nanoparticles and provides a highly stable solid electrolyte interface layer during the cycling, resulting in excellent electrochemical performances and significantly improved high thermal stability.

Rechargeable lithium-ion batteries (LIBs) have been developed as the most promising power source technology for portable electronics (e.g., cell phones, laptop computers, digital cameras, etc.) and vehicles (e.g., hybrid vehicle, electric vehicle, etc.). ${ }^{1,2}$ In the last decade, substantial efforts have been devoted to the replacement of conventional carbon-based anode materials in LIBs with alternatives that allow a high energy density. ${ }^{3-5}$

Silicon is an attractive anode material for next-generation LIBs owing to its abundant availability, its low discharge potential $(<0.4$ $\mathrm{V} v$ s. $\mathrm{Li} / \mathrm{Li}^{+}$) and high theoretical gravimetric capacity (3579 mAh $\mathrm{g}^{-1}$ at room temperature). ${ }^{6-8}$ However, the practical use of $\mathrm{Si}$ anode material in LIBs is hindered by its poor cyclability resulting from the low intrinsic electrical conductivity and the huge volume change (>300\%). ${ }^{9,10}$ The use of nanostructured materials is an effective approach to solve this issue. Nanostructured $\mathrm{Si}$ anode materials, including nanoparticles, ${ }^{11,12}$ nanowires, ${ }^{4,13,14}$ nanotubes, ${ }^{15}$ hollow spheres, ${ }^{16}$ and porous structures, ${ }^{17,18}$ showed significantly improved cycle performances by accommodating the large volume change.

An alternative approach for improving the stability of $\mathrm{Si}$ is to use surface coating. The surface of an electrode material can greatly influence the electrochemical properties. Considering the potentials at which the Si host alloys with lithium, electrolyte components, especially carbonate esters, will be inevitably reduced into species that are structurally similar to that identified on graphitic anodes. ${ }^{19}$ However, fresh $\mathrm{Si}$ surfaces are created

Interdisciplinary School of Green Energy, Ulsan National Institute of Science and Technology, Ulsan, Korea 689-798. E-mail: spark@unist.ac.kr; Fax: +82-52-217-2909 $\dagger$ Electronic supplementary information (ESI) available: EDAX profile and XPS spectra of $\mathrm{Ti}_{x} \mathrm{Si}_{y}$-coated Si particles. See DOI: 10.1039/c2ra23365g repeatedly in each cycle and due to the local instability caused by the huge volume change associated with the lithium insertion/ extraction process, an additional reduction of electrolytes takes place to cover those newly exposed surfaces. This continuous process consumes the limited $\mathrm{Li}^{+}$source, builds up a thick solid electrolyte interface (SEI) layer on the $\mathrm{Si}$ active materials, and would eventually disable the cell. ${ }^{19,20}$ Therefore, a uniform and compact SEI layer on the electrode surface may enhance the efficiency and cycling stability of the electrode. Typically, carbonbased materials, ${ }^{21-23}$ metal particles, ${ }^{18,24-29}$ metal oxide particles, ${ }^{30,31}$ and conductive polymers ${ }^{32,33}$ have been used as coating materials to enhance the electrical conductivity of $\mathrm{Si}$ and to form a stable SEI layer, resulting in improved electrochemical performances.

As another simple method, a silicothermic reduction process can provide an attractive means to coat titanium silicide $\left(\mathrm{Ti}_{x} \mathrm{Si}_{y}\right)$ on the surface of $\mathrm{Si}$. Since the $\mathrm{Ti}_{x} \mathrm{Si}_{y}$ is light-weight, highly electrically conductive, and thermally stable, when it is combined with $\mathrm{Si}$ particles significantly improved electrochemical performances can be expected. ${ }^{34-36}$ For example, Zhou et al. reported the synthesis of hetero-nanostructures consisting of $\mathrm{TiSi}_{2}$ nanonets and $\mathrm{Si}$ nanoparticles via a chemical vapor deposition process. The hetero-nanostructured anode materials exhibited remarkable electrochemical performances, including high capacity and long cycling life. However, the amount of inactive $\mathrm{TiSi}_{2}$ should be minimized to make high energy density LIBs. ${ }^{36}$

Herein, we report a simple synthesis of $\mathrm{Ti}_{\mathrm{x}} \mathrm{Si}_{\mathrm{y}}$ coated $\mathrm{Si}$ nanoparticles via a silicothermic reduction process, in which $\mathrm{Si}$ acts as the reducing agent, while titanium oxide is used as a source material of Ti.t The titanium silicide enhances the electrical conductivity of Si nanoparticles and provides a highly stable SEI layer during the cycling, resulting in superior electrochemical performances including a high reversible capacity $\left(1470 \mathrm{mAh} \mathrm{g}^{-1}\right)$ and a high rate capability $\left(1150 \mathrm{mAh} \mathrm{g}^{-1}\right.$ at $20 \mathrm{C}$ rate). Moreover, the $\mathrm{Ti}_{x} \mathrm{Si}_{y}$-coated $\mathrm{Si}$ electrodes showed significantly improved high thermal stability, compared to bare Si electrodes.

The synthetic approach of $\mathrm{Ti}_{x} \mathrm{Si}_{y}$-coated $\mathrm{Si}$ nanoparticles is briefly described in the schematic illustration of Fig. 1. We developed a simple wet-chemical synthetic route to evenly coat 

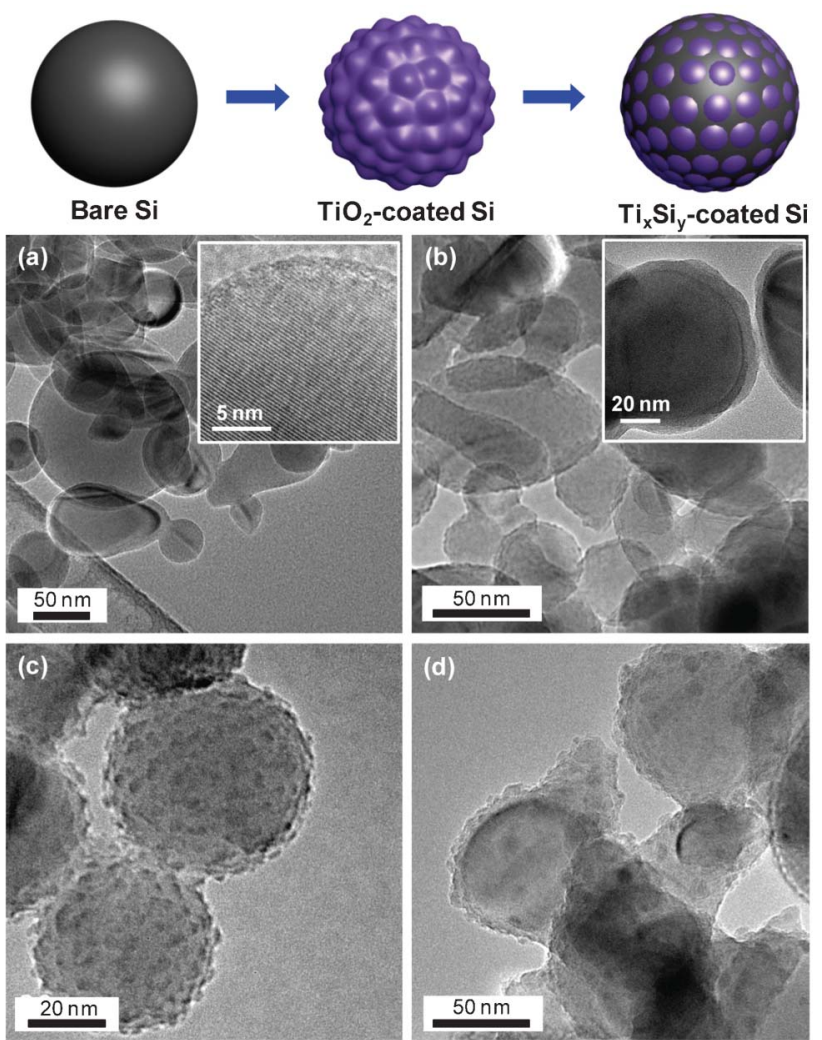

Fig. 1 Synthesis of $\mathrm{Ti}_{x} \mathrm{Si}_{y}$-coated $\mathrm{Si}$ nanoparticles. Top: Schematic illustration preparing $\mathrm{Ti}_{x} \mathrm{Si}_{y}$ layer on the surface of Si particles. Bottom: (a) TEM image of bare Si particles and magnified TEM image (inset of panel a) showing crystalline Si core and $\mathrm{SiO}_{2}$ shell, (b) TEM image of $\mathrm{TiO}_{2}$-coated Si particles and magnified image (inset of panel b) showing thickness of $\mathrm{TiO}_{2}$ layer, (c) TEM image of $\mathrm{TiO}_{2}$-coated Si particles annealed at $450{ }^{\circ} \mathrm{C}$, and (d) TEM image of $\mathrm{Ti}_{x} \mathrm{Si}_{y}$-coated $\mathrm{Si}$ particles obtained by annealing at $1000^{\circ} \mathrm{C}$.

$\mathrm{TiO}_{2}$ onto the surface of Si particles by controlled hydrolysis of the titanium precursors. A subsequent two-step annealing process led to the formation of $\mathrm{Ti}_{x} \mathrm{Si}_{y}$-coated $\mathrm{Si}$ particles. A detailed explanation of the synthetic procedures is given in the experimental section.

Fig. 1a presents a transmission electron microscope (TEM) image of Si nanoparticles, showing that the particles consist of a crystalline Si core (ranging from 30 to $100 \mathrm{~nm}$ in diameter) and an $\mathrm{SiO}_{2}$ shell with thickness of $\sim 1 \mathrm{~nm}$ (Inset of Fig. 1a). When equal amounts of titanium tetrabutoxide and $\mathrm{H}_{2} \mathrm{O}$ were refluxed in a mixture of ethylene glycol/ethanol in the presence of $1 \mathrm{~g} \mathrm{Si}$ particles, the amorphous $\mathrm{TiO}_{2}$ precursor was evenly coated on the surface of the Si particles with an average thickness of $\sim 10 \mathrm{~nm}$ (Inset of Fig. 1b). The Ti amount of $2.4 \mathrm{wt} \%$ was confirmed by inductively coupled plasma mass spectrometry (ICP) analysis. With an increasing $\mathrm{Ti}$ precursor, the $\mathrm{Ti}$ contents in the final products were linearly increased (Fig. S1, ESI $\dagger$ ). The $\mathrm{TiO}_{2}$ coated $\mathrm{Si}$ particles were subsequently annealed at $450{ }^{\circ} \mathrm{C}$ for $1 \mathrm{~h}$ to prepare $\mathrm{TiO}_{2}$-decorated Si powders. Consequently, amorphous $\mathrm{TiO}_{2}$ were transformed to crystalline $\mathrm{TiO}_{2}$ having an average particle size of 5 $\mathrm{nm}$ (Fig. 1c). As the $\mathrm{TiO}_{2}$-decorated $\mathrm{Si}$ particles were further annealed at $1000{ }^{\circ} \mathrm{C}$ for $1 \mathrm{~h}$ in argon, the $\mathrm{TiO}_{2}$ was transformed to
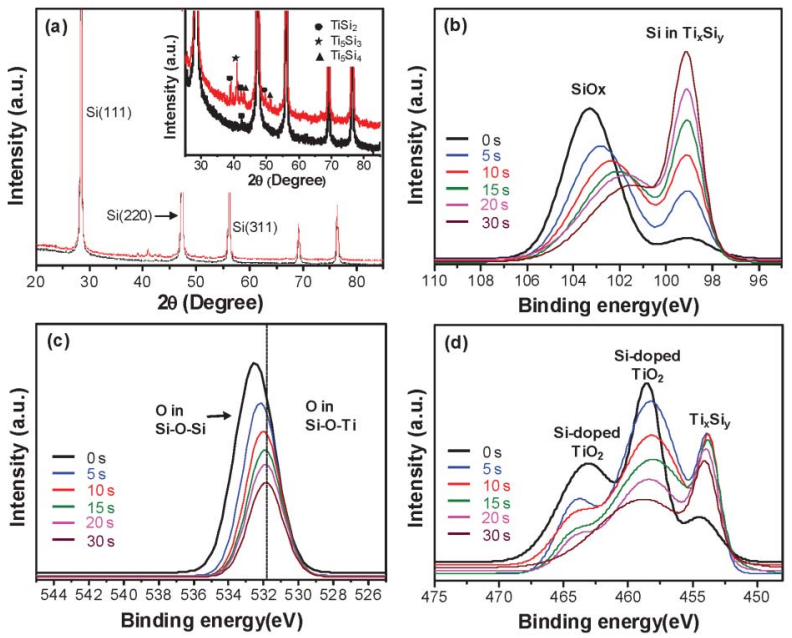

Fig. 2 Characterization of $\mathrm{Ti}_{x} \mathrm{Si}_{y}$-coated Si nanoparticles. (a) XRD patterns show $\mathrm{Ti}_{x} \mathrm{Si}_{y}$-coated Si particles annealed at $450{ }^{\circ} \mathrm{C}$ (black line) and $1000{ }^{\circ} \mathrm{C}$ (red line). In the inset, $\mathrm{TiSi}_{2}, \mathrm{Ti}_{5} \mathrm{Si}_{3}$, and $\mathrm{Ti}_{5} \mathrm{Si}_{4}$ phases were clearly observed. (b) XPS spectra of the $\mathrm{Si}$ $2 p$ core level shows existence of a $\mathrm{Ti}_{x} \mathrm{Si}_{y}$ layer and a formation of Ti-O-Si. XPS depth profiling data indicates the successful synthesis of $\mathrm{Ti}_{x} \mathrm{Si}_{y}$ layers on the surface of $\mathrm{Si}$ particles. XPS spectra of (c) O 1s and (d) Ti $2 p$ core levels confirm the formation of strong bonding between $\mathrm{Si}$ and $\mathrm{TiO}_{2}(\mathrm{Ti}-\mathrm{O}-\mathrm{Si})$ and $\mathrm{Ti}_{x} \mathrm{Si}_{y}$ phases.

$\mathrm{Ti}_{x} \mathrm{Si}_{y}$ via a silicothermic reduction process, as will be discussed later (Fig. 1d).

To investigate the formation mechanism of $\mathrm{Ti}_{x} \mathrm{Si}_{y}$-coated $\mathrm{Si}$ particles, we obtained X-ray diffraction (XRD) patterns photoelectron spectroscopy (XPS) results. XRD patterns of $\mathrm{TiO}_{2}$ decorated $\mathrm{Si}$ annealed at $450{ }^{\circ} \mathrm{C}$ showed that crystalline Si peaks were clearly observed (black line in Fig. 2a), while a weak peak of crystalline $\mathrm{TiSi}_{2}$ phase was detected at $42^{\circ}$, as indicated in the inset of Fig. 2(a). When the annealing temperature was increased to $1000{ }^{\circ} \mathrm{C}$, the intensity of the $\mathrm{TiSi}_{2}$ peak was significantly increased (solid circle in the inset) and a new phase of $\mathrm{Ti}_{5} \mathrm{Si}_{3}$ (solid star) and $\mathrm{Ti}_{5} \mathrm{Si}_{4}$ (solid triangle) was developed, (the inset of Fig. 2a). The $\mathrm{Ti}_{5} \mathrm{Si}_{3}$ and $\mathrm{Ti}_{5} \mathrm{Si}_{4}$ phases were formed as the $\mathrm{TiSi}_{2}$ phase was further reacted with additional Ti, as marked in the Ti-Si binary phase diagram. ${ }^{37}$

In order to characterize the oxidation states of the silicon, oxygen, and titanium ions, XPS spectra of titanium-silicide coated Si samples were obtained. The structures of the coating layers were investigated through depth profiling by argon ion. The binding energies of Si 2p appearing at $99 \mathrm{eV}$ represent silicon species in the $\mathrm{Ti}_{x} \mathrm{Si}_{y}$, indicating that $\mathrm{Ti}_{x} \mathrm{Si}_{y}$-coated $\mathrm{Si}$ is successfully synthesized (Fig. 2b). Also, based on the XPS spectra ranging from 103.5 to 101 $\mathrm{eV}$, pure $\mathrm{SiO}_{x}$ exists in the outermost shell and Ti-associated $\mathrm{SiO}_{x}$ in the inner layers was detected with a short time etching, implying that $\mathrm{Si}-\mathrm{O}-\mathrm{Ti}$ bonds may be formed (Fig. 2b). ${ }^{38}$ From the binding energy of $\mathrm{O} 1 \mathrm{~s}$ appearing at $533 \mathrm{eV}(\mathrm{Si}-\mathrm{O}-\mathrm{Si})$ and $532 \mathrm{eV}$ ( $\mathrm{Si}-\mathrm{O}-\mathrm{Ti}$ ), the formation of $\mathrm{Si}-\mathrm{O}-\mathrm{Ti}$ was confirmed, revealing the strong interaction between $\mathrm{TiO}_{2}$ and $\mathrm{Si}$ (Fig. 2c). ${ }^{39}$ The XPS spectra of the Ti $2 \mathrm{p}$ core level reconfirmed the formation of Si-doped $\mathrm{TiO}_{2}$ and $\mathrm{Ti}_{x} \mathrm{Si}_{y}$. In the outermost shell regions, the peaks appearing at 458.5 and $464.3 \mathrm{eV}$ correspond to the core level of $\mathrm{Ti} 2 \mathrm{p}$ of $\mathrm{TiO}_{2}$. $\mathrm{Ti}$ 
2p peaks corresponding to the $\mathrm{Si}$-dope $\mathrm{TiO}_{2}$ and the $\mathrm{Ti}_{x} \mathrm{Si}_{y}$ were gradually increased through deep depth profiling (Fig. 2d). ${ }^{40}$

The formation of $\mathrm{Ti}_{x} \mathrm{Si}_{y}$ layers can be described as follows: (i) When the $\mathrm{TiO}_{2}$ coating layers were heated to $>900{ }^{\circ} \mathrm{C}$, the dissociation of $\mathrm{TiO}_{2}$ is fast, leaving oxygen vacancies; ${ }^{41}$ (ii) At the same temperature, $\mathrm{Si}$ atoms easily diffuse into the dissociated and remaining $\mathrm{TiO}_{2}$ layers to make $\mathrm{TiSi}_{2}$ layers; (iii) The little remaining oxygen may react with the $\mathrm{Si}$ to make $\mathrm{SiO}$ at the shell regions, in which the $\mathrm{SiO}$ will be evaporated at $>900{ }^{\circ} \mathrm{C}$; (iv) Finally, the $\mathrm{Ti}_{5} \mathrm{Si}_{3}$ and $\mathrm{Ti}_{5} \mathrm{Si}_{4}$ phases are formed by the reaction of the preformed $\mathrm{TiSi}_{2}$ phase and additional dissociated Ti. The overall reaction to form $\mathrm{Ti}_{x} \mathrm{Si}_{y}$ is denoted in the following equations: ${ }^{42}$

$$
\begin{gathered}
\mathrm{Ti}+2 \mathrm{Si} \rightarrow \mathrm{TiSi}_{2} \\
\mathrm{TiO}_{2}+4 \mathrm{Si} \rightarrow \mathrm{TiSi}_{2}+2 \mathrm{SiO} \uparrow\left(>900{ }^{\circ} \mathrm{C}\right) \\
y \mathrm{TiSi}_{2}+(2 x-y) \mathrm{Ti} \rightarrow 2 \mathrm{Ti}_{x} \mathrm{Si}_{y}
\end{gathered}
$$

The electrochemical performance of the $\mathrm{Ti}_{x} \mathrm{Si}_{y}$-coated $\mathrm{Si}$ particlest (Ti contents of $2.3 \mathrm{wt} \%$ ) as the anodes in LIBs was tested by galvanostatic discharging and charging at a $0.1-20 \mathrm{C}$ rate in the range of $0.005 \mathrm{~V}$ to $1.2 \mathrm{~V}$. The first discharge and charge capacity of bare Si at a $0.1 \mathrm{C}$ rate are 1950 and $1550 \mathrm{mAh} \mathrm{g}^{-1}$, corresponding to a coulombic efficiency of $79.4 \%$ (Fig. 3a). Whereas, the first charge capacity of the $\mathrm{Ti}_{x} \mathrm{Si}_{y}$-coated $\mathrm{Si}$ at a $0.1 \mathrm{C}$ rate is $1470 \mathrm{mAh} \mathrm{g}^{-1}$ with an increased coulombic efficiency of 83.5\% (Fig. 3b). The enhanced coulombic efficiency of the first cycle may be due to the uniform $\mathrm{Ti}_{x} \mathrm{Si}_{y}$ coating layer, which can maintain a SEI layer on the surface of the Si particles and reduce the direct contact between $\mathrm{Si}$ and the electrolyte.

When the $\mathrm{Ti}_{x} \mathrm{Si}_{y}$-coated $\mathrm{Si}$ electrode was cycled to 90 cycles at a rate of $0.2 \mathrm{C}$ (lithiation) and $0.5 \mathrm{C}$ (delithiation), a high reversible capacity of $1430 \mathrm{mAh} \mathrm{g}^{-1}$ was exhibited, corresponding to the
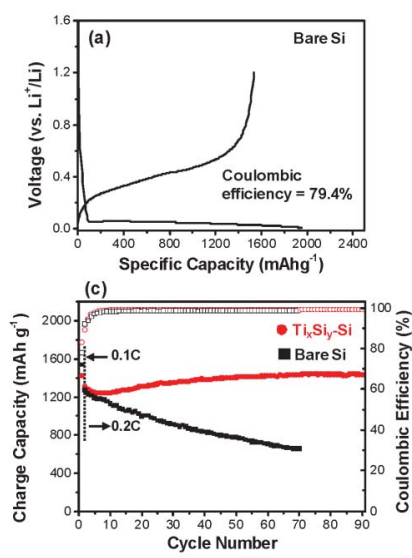

Fig. 3 Electrochemical performances of $\mathrm{Ti}_{x} \mathrm{Si}_{y}$-coated $\mathrm{Si}$ and bare $\mathrm{Si}$ anodes. First cycle voltage profiles of (a) bare $\mathrm{Si}$ and (b) $\mathrm{Ti}_{x} \mathrm{Si}_{y}$-coated $\mathrm{Si}$ are obtained at $0.1 \mathrm{C}$ (1st cycle) in the range of 0.005-1.2 V. (c) Cycling performances of both electrodes are obtained at $0.1 \mathrm{C}$ (first cycle) and $0.2 \mathrm{C}$ (from second cycle). (d) Rate capabilities of $\mathrm{Ti}_{x} \mathrm{Si}_{y}$-coated Si (solid circle) and bare Si (solid square) were obtained at $0.2 \mathrm{C}-20 \mathrm{C}$ rates. capacity retention of $>99 \%$ (compared to initial capacity) (Fig. 3c). In contrast, the bare Si electrode showed a fast capacity fading with capacity retention of $51 \%$ after 70 cycles (Fig. 3c). It is attributed to poor electrical conductivity and the formation of an unstable SEI layer. ${ }^{7}$ Cross-sectional SEM images of bare and $\mathrm{Ti}_{x} \mathrm{Si}_{y}$-coated $\mathrm{Si}$ showed the thickness of the electrodes before and after cycling. The bare Si electrode showed the volume expansion of $62.3 \%$, while the $\mathrm{Ti}_{x} \mathrm{Si}_{y}$-coated $\mathrm{Si}$ exhibited less volume expansion (30\%) due to the coating effect and the stable SEI layer (Fig. S2, ESI†).

Moreover, rate capabilities of both electrodes were investigated at various $\mathrm{C}$ rates $(0.2-20 \mathrm{C}$ rate) between $1.2 \mathrm{~V}$ and $0.005 \mathrm{~V}$ with a fixed discharging rate of $0.2 \mathrm{C}$. The bare Si electrodes exhibited the capacity retention of $66.7 \%$ at a high rate of $10 \mathrm{C}$, compared to that of the $0.2 \mathrm{C}$ rate (Fig. $3 \mathrm{~d}$ ). In contrast, the $\mathrm{Ti}_{x} \mathrm{Si}_{y}$-coated $\mathrm{Si}$ electrode showed significantly enhanced rate capabilities. Even at a high rate of $20 \mathrm{C}$, the capacity retention of the $\mathrm{Ti}_{x} \mathrm{Si}_{y}$-coated $\mathrm{Si}$ was $87.8 \%$ (Fig. 3d). These results suggest that the $\mathrm{Ti}_{x} \mathrm{Si}_{y}$ coating layers play an important role in exhibiting superior electrochemical properties, including highly stable cycling and an excellent rate capability. Since the $\mathrm{Ti}_{x} \mathrm{Si}_{y}$ layers were strongly attached to the $\mathrm{Si}$ interface during the silicothermic reduction process, the $\mathrm{Ti}_{x} \mathrm{Si}_{y^{-}}$ coated Si electrodes may exhibit a highly stable cycling. Moreover, the electrical conductivity of the electrodes prepared with bare $\mathrm{Si}$ was $4.23 \times 10^{-5} \mathrm{~S} \mathrm{~cm}^{-1}$, while the $\mathrm{Ti}_{x} \mathrm{Si}_{y}$-coated $\mathrm{Si}$ electrode showed a significant improvement $\left(1.87 \times 10^{-4} \mathrm{~S} \mathrm{~cm} \mathrm{~cm}^{-1}\right)$, indicating that the $\mathrm{Ti}_{x} \mathrm{Si}_{y}$ layer served as the effective path for electrical conduction.

To prove the stable cycling of $\mathrm{Ti}_{x} \mathrm{Si}_{y}$-coated $\mathrm{Si}$ electrodes, the XPS spectra were obtained before and after cycling. Interestingly, the SEI layer did not discernibly change between the 1st and 40th cycles, supporting good capacity retention of the $\mathrm{Si}$ anodes with the $\mathrm{Ti}_{x} \mathrm{Si}_{y}$ coating layer (Fig. S3 and S4, ESI $\dagger$ ).

In addition, the effect of the $\mathrm{Ti}_{x} \mathrm{Si}_{y}$ coating on the thermal properties of the fully lithiated $\mathrm{Si}$ electrode was investigated by differential scanning calorimetry (DSC). Heating of the fully lithiated bare $\mathrm{Si}$ electrode resulted in distinct and sharp exothermic peaks at around 107, 187, 251, and $262{ }^{\circ} \mathrm{C}$ (Top in Fig. 4a). It is reasonable that the first exothermic peaks at 100-130 ${ }^{\circ} \mathrm{C}$ correspond to thermal decomposition of metastable SEI components. ${ }^{43}$ Heat evolution $\left(55 \mathrm{~J} \mathrm{~g}^{-1}\right)$ for the first exothermic peak of the fully lithiated $\mathrm{Ti}_{x} \mathrm{Si}_{y}$-coated $\mathrm{Si}$ was larger than that of fully lithiated bare $\mathrm{Si}\left(37 \mathrm{~J} \mathrm{~g}^{-1}\right)$ in the presence of an electrolyte. In order to clarify this point, the XPS analysis of the SEI on bare and $\mathrm{Ti}_{x} \mathrm{Si}_{y}$-coated $\mathrm{Si}$ electrodes was performed. From the XPS results, it is clearly seen that a $\mathrm{LiPF}_{6}$ salt, which is thermally unstable and highly reactive with trace water, is trapped in the SEI on the coated Si after 1 cycle (Fig. S3, ESI $\dagger$ ). It should be noted that $\mathrm{PF}_{5}$ formed from $\mathrm{LiPF}_{6}$ decomposes to $\mathrm{POF}_{3}$ in the presence of water traces (in an electrolyte and an electrode) and the reactive $\mathrm{POF}_{3}$ in the electrolyte reacts with carbonate solvents, such as EC and DEC to produce $\mathrm{CO}_{2}$ and $\mathrm{OPF}_{2} \mathrm{ORF}$ at elevated temperatures, as illustrated in the ESI (Fig. S5, ESI†). This kind of reaction may generate additional exothermic heat and results in augmentation of heat evolution for the first exothermic peak of the fully lithiated $\mathrm{Ti}_{x} \mathrm{Si}_{y^{-}}$ coated Si. 


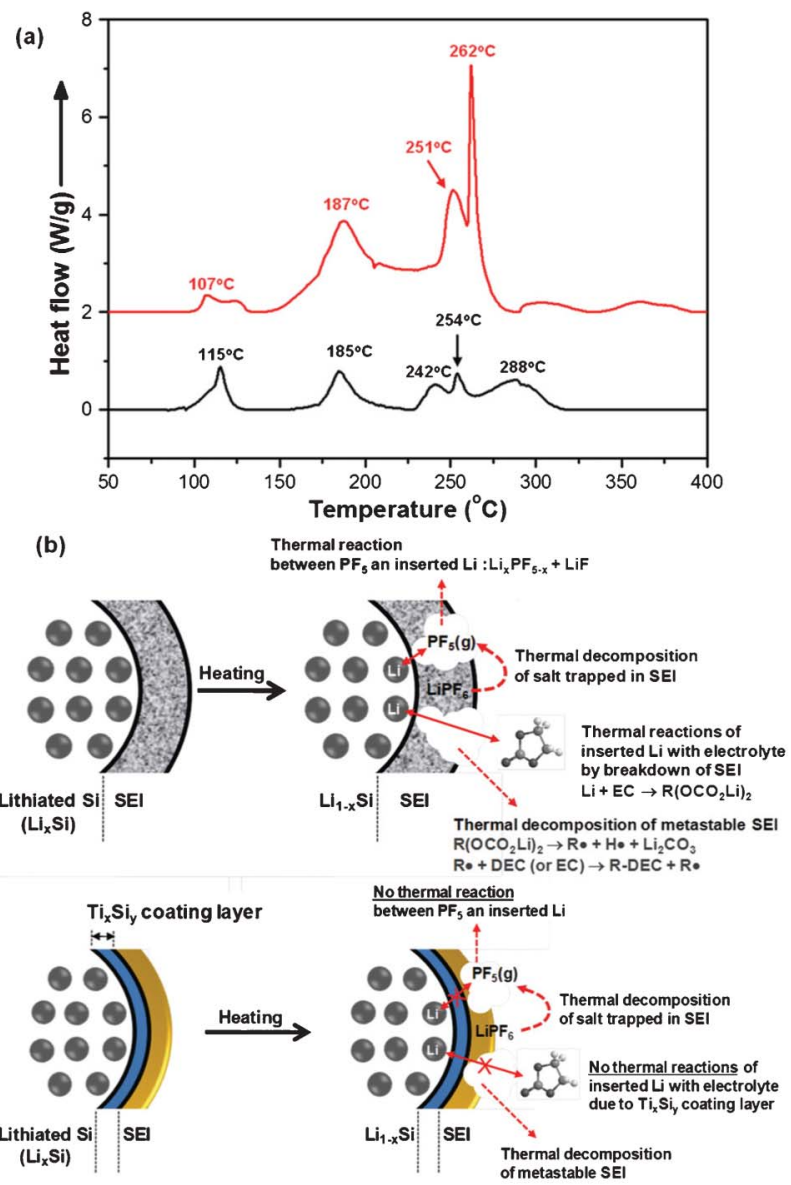

Fig. 4 Thermal stability of bare Si and $\mathrm{Ti}_{x} \mathrm{Si}_{y}$-coated $\mathrm{Si}$ electrodes. (a) DSC profiles of bare $\mathrm{Si}$ and $\mathrm{Ti}_{x} \mathrm{Si}_{y}$-coated $\mathrm{Si}$ electrodes. (b) Schematic illustration showing the thermal decomposition reactions of an electrolyte with lithiated $\mathrm{Si}$ at elevated temperatures.

A DSC heating curve for fully lithiated bare Si shows very large exothermic peaks at $150-320{ }^{\circ} \mathrm{C}$, while the presence of the $\mathrm{Ti}_{x} \mathrm{Si}_{y}$ coating layer on fully lithiated $\mathrm{Si}$ gives broad exothermic peaks with significantly reduced heat (Bottom in Fig. 4a). It indicates that the $\mathrm{Ti}_{x} \mathrm{Si}_{y}$ coating layer effectively mitigated various exothermic reactions caused by the thermal decomposition reactions of an electrolyte with lithiated Si at elevated temperatures, as depicted in Fig. 4(b). When a cell is heated above a certain temperature, exothermic reactions between the electrodes and the electrolyte take place and leads to an increase of the internal cell temperature. If the generated heat is greater than the energy that can be dissipated, the cell temperature will increase rapidly. This temperature growth will accelerate chemical reactions and lead to the production of even more heat, eventually resulting in the thermal runaway of batteries. From this point of view, it can be expected that the $\mathrm{Ti}_{x} \mathrm{Si}_{y}$ coating layer on $\mathrm{Si}$ anode materials improves battery safety because the exothermic heat evolution (324 $\mathrm{J} \mathrm{g}^{-1}$ ) in the overall $80-320{ }^{\circ} \mathrm{C}$ was greatly reduced compared to non-coated Si electrodes $\left(912 \mathrm{~J} \mathrm{~g}^{-1}\right)$.

\section{Conclusions}

We successfully synthesized titanium silicide coated silicon particles via a silicothermic reduction process of $\mathrm{Si}$ and $\mathrm{TiO}_{2}$. The $\mathrm{TiO}_{2}$ layers were evenly coated on the surface of $\mathrm{Si}$ in a solution, and subsequent thermal annealing led to the formation of titanium silicide coated Si particles. Since titanium silicide are electrically conductive and form a highly stable $\mathrm{SEI}$ layer, $\mathrm{Ti}_{x} \mathrm{Si}_{y^{-}}$ coated Si electrodes exhibit high electrochemical performances, including a high specific capacity and an excellent rate capability. Also, the $\mathrm{Ti}_{x} \mathrm{Si}_{y}$-coated $\mathrm{Si}$ electrodes showed significantly improved thermal stability, compared to non-coated Si electrodes. This process opens up a way to make other silicon-based anode materials for high performance lithium-ion batteries.

\section{Acknowledgements}

This work was supported by the MKE/ITRC program of NIPA (NIPA-2012-C1090-1200-0002) and the Conversing Research Center Program through the Ministry of Education, Science and Technology (2011K000637).

\section{Notes and references}

+ Preparation of $T i_{x} S i_{y}$-coated Si particles: Si nanopowder (Sigma-Aldrich, 50 $\mathrm{nm}$ in size) was cleaned in acetone and isopropyl alcohol and dried under nitrogen. In a typical synthesis, $0.2 \mathrm{~mL}$ of titanium tetrabutoxide and 0.2 $\mathrm{mL}$ of $\mathrm{H}_{2} \mathrm{O}$ were refluxed in ethylene glycol/ethanol $(16 \mathrm{~mL} / 4 \mathrm{~mL})$ at $80{ }^{\circ} \mathrm{C}$ for $6 \mathrm{~h}$ in the presence of $1 \mathrm{~g}$ Si particles. As-synthesized $\mathrm{TiO}_{2}$-coated $\mathrm{Si}$ powders were cleaned with ethanol several times and dried at $80^{\circ} \mathrm{C}$ for 12 h. Subsequently, the $\mathrm{TiO}_{2}$-coated Si particles were thermally annealed in a quartz furnace at $450-1000{ }^{\circ} \mathrm{C}$ for $1 \mathrm{~h}$ under argon stream to make $\mathrm{Ti}_{x} \mathrm{Si}_{y^{-}}$ coated Si particles.

Characterization of $T i_{x} S i_{y}$-coated Si particles: The crystal structures of the $\mathrm{Ti}_{x} \mathrm{Si}_{y}$-coated $\mathrm{Si}$ sample were measured by a high power X-ray diffractometer (XRD) on a Rigaku D/MAX at $2500 \mathrm{~V}$ using Ni-filtered $\mathrm{Cu}-\mathrm{K} \alpha$ radiation. TEM images were taken in the bright-field mode using JEM 1400 (JEOL) operated at $120 \mathrm{kV}$ accelerating voltages.

Thermal analyses of lithiated $\mathrm{Ti}_{x} \mathrm{Si}_{y}$-coated Si particles: To measure the thermal properties of lithiated $\mathrm{Si}$ electrodes with electrolytes, coin cells were charged to $0.005 \mathrm{~V} v s$. $\mathrm{Li}^{-\mathrm{Li}^{+}}$and then carefully opened in a dry room. The retrieved electrodes were rinsed in a DMC solvent to remove residual electrolyte and then dried. The resulting lithiated silicon electrode was sealed together with an electrolyte in a hermetic stainless-steel pan (Perkin Elmer). All of the DSC (METTLER TOLEDO DSC 1) measurements were carried out at a heating rate of $5{ }^{\circ} \mathrm{C} \mathrm{min}{ }^{-1}$ in a range of $30-400{ }^{\circ} \mathrm{C}$. The amount of entrapped electrolyte was $50 \mathrm{wt} \%$ based on the lithiated silicon material.

Electrochemical performance: An electrochemical cell test was performed using coin-type half cells (2016R type) by assembly in an argon-filled glove box. $\mathrm{Ti}_{x} \mathrm{Si}_{y}$-coated $\mathrm{Si}$ and bare $\mathrm{Si}$ electrodes for the cell test were composed of $\mathrm{Si}$ active material $(70 \mathrm{wt} \%)$, super $\mathrm{P}$ carbon black $(10 \mathrm{wt} \%)$, and poly(acrylic acid)/sodium carboxymethyl cellulose (wt/wt, 50/50) binder (20 wt $\%$ ). The electrolyte was composed of $1.3 \mathrm{M} \mathrm{LiPF}_{6}$ in a mixture of ethylene carbonate/diethylene carbonate (ED/DEC, 30/70 vol.\%) with $5 \mathrm{wt} \%$ fluoroethylene carbonate (FEC) additive. The cells were cycled at a rate of $0.1-20 \mathrm{C}$ in the range of 0.005 and $1.2 \mathrm{~V}$.

1 J. M. Tarascon and M. Armand, Nature, 2001, 414, 359.

2 P. G. Bruce, B. Scrosati and J.-M. Tarascon, Angew. Chem., Int. Ed., 2008, 47, 2930.

3 M. S. Whittingham, Chem. Rev., 2004, 104, 4271.

4 C. K. Chan, H. Peng, G. Liu, K. McIlwrath, X. F. Zhang, R. A. Huggins and Y. Cui, Nat. Nanotechnol., 2008, 3, 31.

5 A. Magasinski, P. Dixon, B. Herzberg, A. Kvit, J. Ayala and G. Yushin, Nat. Mater., 2010, 9, 353. 
6 T. D. Hatchard and J. R. Dahn, J. Electrochem. Soc., 2004, 151, A838.

7 M. N. Obrovac and L. J. Krause, J. Electrochem. Soc., 2007, 154, A103.

8 X. H. Liu, L. Q. Zhang, L. Zhong, Y. Liu, H. Zheng, J. W. Wang, J. H. Cho, S. A. Dayeh, S. T. Picraux, J. P. Sullivan, S. X. Mao, Z. Z. Ye and J. Y. Huang, Nano Lett., 2011, 11, 2251.

9 U. Kasavajjula, C. Wang and A. J. Appleby, J. Power Sources, 2007, 163, 1003.

10 H. Li, Z. X. Wang, L. Chen and X. J. Huang, Adv. Mater., 2009, 21, 4593.

11 Y. S. Hu, R. Demir-Cakan, M.-M. Titirici, J. O. Muller, R. Schlogl, M. Antonietti and J. Maier, Angew. Chem., Int. Ed., 2008, 47, 1645.

12 P. F. Gao, J. W. Fu, J. Yang, R. G. Lu, J. L. Wang and X. Z. Tang, Phys. Chem. Chem. Phys., 2009, 11, 11101.

13 W. Wang and P. N. Kumta, ACS Nano, 2010, 4, 2233.

14 B. M. Bang, H. Kim, J.-P. Lee, J. Cho and S. Park, Energy Environ. Sci., 2011, 4, 3395.

15 M.-H. Park, M. G. Kim, J. Joo, K. Kim, J. Kim, S. Ahn, Y. Cui and J. Cho, Nano Lett., 2009, 9, 3844.

16 H. Ma, F. Cheng, J. Chen, J. Zhao, C. Li, Z. Tao and J. Liang, Adv. Mater., 2007, 19, 4067.

17 H. Kim, B. Han, J. Choo and J. Cho, Angew. Chem., Int. Ed., 2008, 47, 10151.

18 Y. Yu, L. Gu, C. Zhu, S. Tsukimoto, P. A. van Aken and J. Maier, Adv. Mater., 2010, 22, 2247.

19 K. Wu and A. von Cresce, J. Mater. Chem., 2011, 21, 9849.

20 Q. M. Pan, H. B. Wang and Y. H. Jiang, Electrochem. Commun., 2007, 9, 754.

21 H. Yoo, J.-I. Lee, H. Kim, J.-P. Lee, J. Cho and S. Park, Nano Lett., 2011, 11, 4324.

22 L. F. Cui, Y. Yang, C. M. Hsu and Y. Cui, Nano Lett., 2009, 9, 3370 .

23 Y. S. Hu, P. Adelhelm, B. M. Smarsly and J. Maier, ChemSusChem, 2010, 3, 231.

24 S. Murugesan, J. T. Harris, B. A. Korgel and K. J. Stevenson, Chem. Mater., 2012, 24, 1306.
25 Y. L. Kim, H. Y. Lee, S. W. Jang, S. H. Lim, S. J. Lee, H. K. Baik, Y. S. Yoon and S. M. Lee, Electrochim. Acta, 2003, 48, 2593.

26 X. L. Yang, Z. Y. Wen, S. H. Huang, X. J. Zhu and X. F. Zhang, Solid State Ionics, 2006, 177, 2807.

27 J. B. Kim, H. Y. Lee, K. S. Lee, S. H. Lim and S. M. Lee, Electrochem. Commun., 2003, 5, 544.

28 J. W. Kim, J. H. Ryu, K. T. Lee and S. M. Oh, J. Power Sources, 2005, 147, 227.

29 D. C. Johnson, J. M. Mosby, S. C. Riha and A. L. Prieto, J. Mater. Chem., 2010, 20, 1993.

30 Y. He, X. Yu, Y. Wang, H. Li and X. Huang, Adv. Mater., 2011, 23, 4938.

31 H. Wu, G. Chan, J. W. Choi, I. Ryu, Y. Yao, M. T. McDowell, S. W. Lee, A. Jackson, Y. Yang, L. Hu and Y. Cui, Nat. Nanotechnol., 2012, 7, 310.

32 Y. Yao, N. Liu, M. T. McDowell, M. Pasta and Y. Cui, Energy Environ. Sci., 2012, 5, 7927.

33 Z. P. GuO, J. Z. Wang, H. K. Liu and S. X. Dou, J. Power Sources, 2005, 146, 448.

34 R. W. Mann, L. A. Clevenger, P. D. Agnello and F. R. White, IBM J. Res. Dev., 1995, 39, 403.

35 Z. Ma, L. H. Allen and D. D. J. Allman, Appl. Phys. Lett., 1995, 77, 4383.

36 S. Zhou, X. Liu and D. Wang, Nano Lett., 2010, 10, 860.

37 T. B. Massalsky, Binary Alloy Phase Diagram, ASM, 1990, p.3370.

38 Z. Jiang, X. Dai and H. Middleton, Mater. Sci. Eng., B, 2011, 176, 79.

39 P. M. Kumar, S. Badrinarayanan and M. Sastry, Thin Solid Films, 2000, 358, 122.

40 G. B. Song, H. Joly, F. S. Liu, T. J. Peng, P. Wan and J. K. Liang, Appl. Surf. Sci., 2003, 220, 159.

41 M. Berti, A. V. Drigo, C. Cohen, J. Siejka, G. G. Bentini, R. Nipoti and S. Guerri, J. Appl. Phys., 1984, 55, 3558.

42 F. Zhao, X. Cui, B. Wang and J. G. Hou, Appl. Surf. Sci., 2006, 253, 2785.

43 N.-S. Choi, I. A. Profatilova, S.-S. Kim and E.-H. Song, Thermochim. Acta, 2008, 480, 10. 